\title{
Treatment of gonorrhoea in Singapore using penicillin plus probenecid
}

\author{
R. N. T. THIN \\ British Military Hospital, Singapore
}

Willcox (1970), in reviewing the problems of treating gonorrhoea in South-East Asia, noted that relatively large doses of penicillin had been used in the region for the last 10 years, but that nevertheless failure rates of 30 per cent. and higher had often been reported. When treating gonorrhoea acquired in the Philippines and Hong Kong, Holmes, Johnson, and Floyd (1967a) found that treatment with probenecid and penicillin gave better results than penicillin alone. Maurer and Schneider (1969) reported similar experience in Vietnam.

The object of this paper is to present the results of treating gonorrhoea among servicemen in Singapore with two regimes of probenecid and penicillin.

\section{Methods}

Diagnosis was based on results of Gram-stained smears and cultures in all cases. Material for culture was collected on charcoal swabs which were immediately placed in Stuart's transport medium. Within a few hours they were plated on to McLeod's chocolate agar. Neisseria gonorrhoeae was identified by colonial appearance, oxidase reaction, and results of sugar fermentation tests.

In 1970 the standard treatment was $1 \mathrm{~g}$. probenecid orally followed 15 to 30 minutes later by 5 m.u. benzyl penicillin made up in $8 \mathrm{ml}$. of 0.5 per cent. lignocaine and given in a single injection. In 1971 the standard treatment was $1 \mathrm{~g}$. probenecid by mouth followed 15 to 30 minutes later by an injection of $\mathbf{2 . 4}$ m.u. Distaquaine Fortified $(1.8 \mathrm{~m} . u$. procaine penicillin plus $600,000 \mathrm{u}$. benzyl penicillin, Dista) and $0.5 \mathrm{~g}$. probenecid 12 and 18 hours later.

Efforts were made to see patients 1 day, 1 week, 2 weeks, 1 month, 2 months, and 3 months after treatment. At each visit patients were encouraged to attend before passing urine in the morning, and about half of them did so. Any urethral discharge was examined microscopically and a culture was taken. The urine was examined by the two-glass test. Serum tests for syphilis were performed at the first visit and monthly thereafter for 3 months. Prostatic secretion was examined 3 months after treatment. Patients who developed non-gonococcal urethritis

Present address: The Royal Infirmary, Edinburgh, EH3 9YW
10 or more days after treatment for gonorrhoea (postgonococcal urethritis) were given $250 \mathrm{mg}$. tetracycline four times a day for 5 days.

In distinguishing relapse from re-infection, the suggestion of Evans (1966) was followed; namely, if gonococci reappear within 14 days of treatment and if the patient denies further intercourse, the infection is considered to have relapsed; the reappearance of gonococci after 14 days is considered to be due to re-infection, regardless of the patient's statements.

\section{Findings}

GROUP TREATED WITH PROBENECID AND BENZYL PENICILLIN IN 1970

\section{Patients}

Between January 1 and December 31, 1970, there were 400 cases of gonococcal urethritis among 383 British, Australian, New Zealand, Gurkha, and Malay servicemen treated with probenecid and benzyl penicillin.

In 363 cases the results of Gram-stained smears and cultures were positive, in five cases the results of Gram-stained smears were negative and cultures were positive, and in thirty cases the results of Gram-stained smears were positive and cultures were negative. In addition, 106 out of 109 cases tested had positive results by immunofluorescent stained smears and in two cases the results of these smears alone were positive (Thin, Green, and Nicol, 1973).

In 373 cases the infection had been acquired in Singapore. In the remaining cases infection had been acquired in various places in South-East Asia, Malta, Nepal, and New Zealand.

\section{Results}

Five ( 1.3 per cent.) of the 378 patients seen at least once after treatment relapsed (Table I); all five had acquired their infection in Singapore. Details of follow-up are shown in Table II. Post-gonococcal urethritis developed in 26 patients (Table III). 
TABLE I Results of treatment

\begin{tabular}{|c|c|c|c|c|}
\hline \multirow[b]{2}{*}{ Treatment } & \multirow[b]{2}{*}{ No. treated } & \multirow[b]{2}{*}{ No. followed } & \multicolumn{2}{|c|}{ Relapsed } \\
\hline & & & No. & Per cent. \\
\hline \multirow{2}{*}{$\begin{array}{l}\text { Probenecid plus } \\
\text { benzyl-penicillin } \\
\text { Probenecid plus } \\
\text { fortified penicillin }\end{array}$} & 400 & 378 & $5^{a}$ & $1 \cdot 3$ \\
\hline & 119 & 118 & $5^{b}$ & $4 \cdot 2$ \\
\hline
\end{tabular}

aFour British and one New Zealander

bAll British

TABLE II Details of follow up

\begin{tabular}{|c|c|c|c|c|c|}
\hline \multirow[b]{2}{*}{ Treatment } & \multirow[b]{2}{*}{ No. treated } & \multicolumn{4}{|c|}{ Numbers seen after } \\
\hline & & 1 day & 1 week & 1 month & 3 months \\
\hline $\begin{array}{l}\text { Probenecid } \\
\text { plus benzyl } \\
\text { penicillin } \\
\text { Probenecid }\end{array}$ & 400 & 378 & 360 & 326 & 297 \\
\hline penicillin & 119 & 118 & 111 & 109 & 63 \\
\hline
\end{tabular}

TABLE III Incidence of post-gonococcal urethritis in penicillin-treated cases

\begin{tabular}{lllll}
\hline Treatment & No. treated & & $\begin{array}{l}\text { Post-gonococcal } \\
\text { urethritis }\end{array}$ \\
\cline { 1 - 1 } \cline { 4 - 5 } Probenecid plus benzyl penicillin & & 400 & & Per cent. \\
Probenecid plus fortified penicillin & 119 & & 6.5 \\
\hline
\end{tabular}

Percentages are based on those treated, and not on those followed as in Table I

Gram-stained smears and cultures gave positive results in all cases which relapsed.

GROUP TREATED WITH PROBENECID AND DISTAQUAINE FORTIFIED IN 1971

\section{Patients}

Between February 9 and June 1, 1971, there were 119 cases of gonococcal urethritis among 118 British, Australian, New Zealand, Gurkha, and Malay servicemen treated with probenecid and Distaquaine Fortified. Fifteen of these cases had also figured in the 1970 series.

In 98 cases the results of Gram-stained smears and cultures were positive, in one case the result of the Gram-stained smear was negative and the culture was positive, and in twenty cases the results of the Gram-stained smears were positive and the cultures were negative.

In 108 cases, the infection had been acquired in Singapore, and in the remainder it had been acquired in other places in South-East Asia.

\section{Results}

Five ( $4 \cdot 2$ per cent.) of the 118 patients seen at least once after treatment relapsed (Table I); all five had acquired their infection in Singapore. Details of follow up are shown in Table II. Nine patients developed post-gonococcal urethritis (Table III).

Gram-stained smears and cultures gave positive results in all cases which relapsed.

\section{KANAMYCIN}

During the same periods in 1970 and 1971, there were 28 cases of gonococcal urethritis treated with 2 g. kanamycin and five (18 per cent.) of them relapsed. None developed post-gonococcal urethritis.

\section{RE-INFECTION}

In four cases there was a recurrence of gonorrhoea during the 14 days after treatment, but the patients admitted further intercourse and were considered to have been re-infected. In another 24 cases gonorrhoea was diagnosed during the follow-up period of 15 days to 3 months. All these patients had positive culture results.

\section{Discussion}

Failure rates were 1.3 per cent. with probenecid plus benzyl penicillin, and 4.2 per cent. with probenecid plus Distaquaine Fortified. These findings compare favourably with many of the reports from S.E. Asia quoted by Willcox (1970). Maurer and Schneider (1969) had $7 \cdot 7$ per cent. of failures among 91 cases treated with probenecid and 2.4 m.u. procaine penicillin in Vietnam. Holmes and others (1967a), using a similar regime, reported only 1.7 per cent. of failures in 58 patients who acquired gonorrhoea in the Philippines. The sensitivity results quoted by these authors indicate that their cases had fewer strains of gonococci relatively resistant to penicillin than there were in Singapore in 1970, according to Morton and Leong (1971).

These last authors reported that 84 per cent. of 96 unselected strains of gonococci collected in Singapore were relatively resistant to penicillin. Of these strains, 22 came from cases reported here, and their sensitivity pattern was the same as that of the remainder which mostly came from patients who acquired their infection from the same group of prostitutes. Phillips, Rimmer, Ridley, Lynn, and Warren (1970) found that only 40 per cent. of 96 strains of gonococci collected in central London were relatively resistant to penicillin. Some of the cultures studied by Phillips and others (1970) came from cases treated by Gray, Phillips, and Nicol (1970). The latter reported a failure rate of 0.5 per cent. 
among 200 cases treated with $1 \mathrm{~g}$. probenecid and 5 m.u. benzyl penicillin, and $3 \cdot 1$ per cent. among 217 cases treated with 2.4 m.u. Distaquaine Fortified alone. The results in the cases reported here show that the schedules used were satisfactory for treating gonorrhoea in a population which had twice as many strains relatively resistant to penicillin as there were in London.

The mean incidence of post-gonococcal urethritis was 7.0 per cent. in the present series. Holmes, Johnson, Floyd, and Kvale (1967b) found that 64 per cent. of cases of gonorrhoea treated with probenecid plus procaine penicillin, and 27 per cent. of a smaller series treated with tetracycline developed post-gonococcal urethritis. Maurer and Schneider (1969) observed post-gonococcal urethritis in 13 to 15 per cent. of cases of gonorrhoea treated with penicillin, but the syndrome occurred in only $7 \cdot 1$ per cent. of cases treated with tetracycline. Gray and others (1970) reported a lower incidence of postgonococcal urethritis after initial treatment with doxycycline than after penicillin. Holmes and others (1967b) suggested that the routine use of penicillin for treating gonorrhoea should be carefully examined in view of their findings. However, the incidence of post-gonococcal urethritis in the present series shows that the syndrome is not always common.

Although only a few cases were treated with kanamycin, the failure rate of 18 per cent. was clearly unsatisfactory compared with the results achieved by the use of probenecid and penicillin. Kanamycin should therefore be given only to selected patients such as those allergic to penicillin.

The response to $1 \mathrm{~g}$. probenecid followed by 5 m.u. benzyl penicillin indicates that this is the treatment of choice in Singapore at present. It is simple to administer, is tolerated well by the patients, fulfils the criteria for ideal treatment outlined by Morton and Leong (1971), and conforms with the recommendations made in the British Medical fournal (1971). Furthermore, widespread use of this regime in Singapore should lower the proportion of strains in the population which are relatively resistant to penicillin, as Olsen and Lomholt (1969) demonstrated in Greenland.

\section{Summary}

The results are described of treating two groups of servicemen in Singapore suffering from gonorrhoea. $1 \mathrm{~g}$. probenecid followed 15 to $30 \mathrm{~min}$ later by $5 \mathrm{~m}$.u. benzyl penicillin was given to 400 patients and five (1.3 per cent. of those followed) relapsed. $1 \mathrm{~g}$. probenecid followed by 2.4 m.u. Distaquaine
Fortified (Dista) with 0.5 g. probenecid 12 and $18 \mathrm{hrs}$ later was given to 119 patients, and five (4.2 per cent. of those followed) relapsed. These results appear to be satisfactory, in view of the proportion of strains of gonococci relatively resistant to penicillin in Singapore, and are much better than those in certain other series reported from S.E. Asia. Postgonococcal urethritis was not a problem. Five of 28 cases treated with $2 \mathrm{~g}$. kanamycin relapsed.

It is concluded that the treatment of choice for gonorrhoea in Singapore is $1 \mathrm{~g}$. probenecid followed by $5 \mathrm{~m} . \mathrm{u}$. benzyl penicillin.

\section{References}

British Medical fournal (1971) Leader, 2, 485

Evans, A. J. (1966) Brit. F. vener. Dis., 42, 251

Gray, R. C. F., Phillips, I., and Nicol, C. S. (1970) Ibid., 46, 401

Holmes, K. K., Johnson, D. W., and Floyd, T. M. (1967a) f. Amer. med. Ass., 202, 461

,,--- , and Kvale, P. A. (1967b) Ibid., 202, 467

MAURER, L. H., and SCHNEIDER, T. J. (1969) Ibid., 207, 946

Morton, R. S., and Leong, Y. O. (1971) Singapore med. f., 12, 86

OlsEN, G. A., and Lomholt, G. (1969) Brit. F. vener. Dis., 45, 144

Phillips, I., Rimmer, D., Ridley, M., LyNN, R., and WARREN, C. (1970) Lancet, 1, 263

Thin, R. N. T., Green, F., and Nicol, C. S. (1973) In preparation

Willcox, R. R. (1970) Brit. f. vener. Dis., 46, 217

Traitement de la gonorrhée à Singapour, utilisant pénicilline et probénécide

\section{SOMMAIRE}

On décrit les résultats du traitement de deux groupes de militaires, à Singapour, atteints de gonococcie. 400 malades furent traités par $1 \mathrm{~g}$. de probénécide, suivi 15 à 30 minutes après par 5 m.u. de benzyl pénicilline, il y eut cinq rechutes ( 1,3 pour cent de ceux qui furent suivis). 119 malades furent traités par $1 \mathrm{~g}$. de probénécide suivi par $2 \mathrm{~m} . \mathrm{u}$. de 'Distaquaine renforcée' (Labo. Dista), associé à $0,5 \mathrm{~g}$. de probénécide 12 et 18 heures après; il y eut cinq rechutes $(4,2$ pour cent de ceux qui furent suivis). Ces résultats semblent satisfaisants en égard à la proportion de souches de gonocoques relativement résistantes à la pénicilline à Singapour et sont bien meilleurs que ce que l'on sait de certaines autres séries en Asie du Sud Est. Les urétrites post-gonococciques ne furent pas un problème. Cinq des vingt-huit cas traités par $2 \mathrm{~g}$. de kanamycine ne furent pas guéris ou rechutèrent. On en conclut que le traitement de choix pour la gonococcie à Singapour est $1 \mathrm{~g}$. de probénécide suivi de $5 \mathrm{~m}$.u. de benzylpénicilline. 